\title{
GLUCOSE METABOLISM DISORDERS AND RISK FACTORS OF TYPE 2 DIABETES IN 45-74-YEARS-OLD POPULATION IN RĪGA, LATVIA
}

\author{
Noël C. Barengo*, Dana Misiṇa**, Lauma Zariṇa***, Jānis Kloviṇš***, Dita Ozola***, \\ Andra Dērveniece ${ }^{\star *}$, Linda Tarāsova ${ }^{\star \star \star *}$, and Valdis Pīrāgs ${ }^{\star \star *}$ \\ * Department of Public Health, University of Helsinki, Helsinki, 00014, FINLAND; \\ e-mail: noel.barengo@uku.fi \\ ** Rīga Stradinš University, Dzirciema iela 16, Rīga, LV-1007, LATVIA; \\ e-mail: danamisina@gmail.com; andra.derveniece@gmail.com \\ *** Pauls Stradinš Clinical University Hospital, Pilsoṇu iela 13, Rīga, LV-1002, LATVIA; \\ e-mail: lauma.zarina@stradini.Iv \\ **** Latvian Biomedical Research and Study Centre, Rātsupītes iela 1, Rīga, LV-1067, LATVIA; \\ e-mail: klovins@biomed.lu.Iv; dita.ozola@latviesi.com; linda.tarasova@biomed.lu.lv
}

Contributed by Valdis Pīrāgs

The aims of this study were to investigate the current prevalence of abnormal glucose tolerance (AGT), compare the risk factor profile between persons with and without AGT among 45-74 years-old Latvian men and women, and to validate the Finnish diabetes risk score (FINDRISC) questionnaire in detecting AGT in the middle-aged Latvian population. A cross-sectional survey among the 45-74-years old population randomly selected from the registers of general practitioners in Riga, Latvia was carried out between April 2008 and March 2009. The survey consisted of a questionnaire, measurements such as height, weight, waist circumference, and blood pressure as well as blood oral glucose tolerance test (OGTT), cholesterol and its fractions. Prevalence of obesity, central obesity and physical inactivity were high in the Latvian population. Women with AGT had a worse risk factor profile for T2D and cardiovascular diseases compared to those with normal glucose tolerance. No differences were found in the risk factor profile between men with and without AGT. A high proportion of men and women with more than 11 FINDRISC points had undetected AGT. The FINDRISC questionnaire can be used in clinical practice to detect persons with $A G T$ in the Latvian population.

Key words: abnormal glucose tolerance, FINDRISC, ROC curve, diabetes, screening tool.

\section{INTRODUCTION}

The increasing prevalence of obesity and sedentary lifestyle are the major underlying causes explaining why for type 2 diabetes (T2D) has become one of the fastest growing public health problems worldwide, imposing a high financial burden on health care costs (King et al., 1998; Wild et al., 2004). The World Health Organisation (WHO) has estimated that the number of adults with diabetes will more than double from an estimated 143 million in 1997 to 300 million by 2025 (Kumanyika et al., 2002).

Locally, T2D is increasing also in Latvia due to an increase of the main risk factors of type 2 diabetes: overweight and obesity as well as physical inactivity. The diabetes screening programme (DIA-screen) conducted among persons with risk factors for T2D in Latvia in 2003 indicated a prevalence of type 2 diabetes of $8.2 \%$, impaired glucose tol- erance (IGT) of 5.5\% and impaired fasting glucose (IFG) of $3.8 \%$ (Pirags et al., 2005). The 2006 FINBALT survey among 15-64 year-old Latvians revealed that $32.3 \%$ of men were overweight and $12.3 \%$ obese (Pudule et al., 2007). The respective numbers among women were $27.5 \%$ and $18.1 \%$. Furthermore, physical activity levels were rather low. $38.2 \%$ men and $29.8 \%$ women had 30 minutes of physical activity in 2-3 days during a week. Given the large number of overweight and obese people, these figures may reflect well the problem of glucose metabolism disorders in the middle-aged population in Latvia.

Persons with abnormal glucose tolerance (AGT), which includes impaired glucose tolerance (IGT) and impaired fasting glucose (IFG), are at high risk to develop T2D. Therefore, it is important to identify persons with AGT in order to effectively prevent or delay the onset of T2D. Current evidence shows that the prevention of AGT and T2D is possi- 
ble through lifestyle intervention in persons with impaired glucose tolerance (Pan et al., 1997; Tuomilehto et al., 2001; Knowler et al., 2002). Thus, it is important to identify those people at high risk for $\mathrm{T} 2 \mathrm{D}$ in the population in order to provide early lifestyle interventions aiming at decreasing the risk of T2D and cardiovascular diseases. Measuring blood glucose levels after a two-hour oral glucose tolerance has been the recommended method to identify people with AGT. However, this is an invasive procedure, and costly and time-consuming when used on a large scale. Thus, a simple validated questionnaire may offer a cost-effective tool in detecting people with AGT.

Based on ten-year prospective data on the incidence of T2D in a population-based cohort, the Finnish diabetes risk score (FINDRISC) was developed to identify people at high risk for the future occurrence of type 2 diabetes (Lindström et al., 2003). The FINDRISC questionnaire was later validated in a cross-sectional, population based setting showing a high sensitivity in identifying those with undetected abnormal glucose tolerance (AGT) in the popualtion (Saaristo et al., 2005).

The aims of this study were to investigate the current prevalence of abnormal glucose tolerance (AGT), to compare the risk factor profile between people with and those without AGT among 45-74 year-old Latvian men and women, and to evaluate the performance of the FINDRISC questionnaire in detecting AGT in the middle-aged Latvian population.

\section{MATERIALS AND METHODS}

A cross-sectional survey among the 45-74-years old population of Riga, Latvia was carried out between April 2008 and March 2009. The total population size in Riga in 2008 was 719,613 (Anonims, 2008), for which the register of general practitioners (GPs) covers approximately 97\%. In total, there are 424 GPs working in six main regions of Riga. Each GP is responsible for the persons from a welldefined geographical region. The study group invited all GPs to participate in the study by written invitation followed up by a telephone call. Sixteen GPs agreed to participate (4\%). A random sample of 2001 individuals proportional to the population size of each of the six main regions of Riga and stratified by gender and ten-year age-groups was selected from the participating GPs' registers. The study participants were invited by the GP for a health interview and medical examination. Finally, 85 men and 171 women agreed to participate $(n=256$; response rate $22 \%)$.

The survey consisted of a questionnaire, measurements of height, weight, waist circumference, and blood pressure as well as estimated blood oral glucose tolerance, cholesterol and its fractions.

Consent was obtained from each participant before the interview and examinations. The questionnaire was computer and interviewer based and consisted of questions related to the medical history of a participant as well as various health-related risk factors including glucose metabolism disorders.
Nurses specially trained for the survey procedures measured height, weight, waist circumference and blood pressure. Height was measured to the nearest centimetre. Weight was measured in light clothing. Body mass index (BMI) was calculated as weight $(\mathrm{kg})$ divided by height ${ }^{2}\left(\mathrm{~m}^{2}\right)$. Central obesity was defined by WHO criteria (Anonymous, 2000): waist circumference $\geq 102 \mathrm{~cm}$ and $\geq 88 \mathrm{~cm}$ in men and women, respectively. In addition, central obesity according to the International Diabetes Federation (IDF) definition of metabolic syndrome was also used: $\geq 94 \mathrm{~cm}$ in men and $\geq 80 \mathrm{~cm}$ in women (Anonymous, 2005). Blood pressure was measured on right arm of subjects, seated for five minutes before the measurement. The fifth phase of the Korotkoff's sound was recorded as the diastolic pressure. Blood pressure was measured twice and the mean of these two measurements was used in the analyses.

The survey examination also included an oral glucose tolerance test (OGTT), carried out according to the World Health Organization (WHO) recommendations (Anonymous, 1999b). A $300 \mathrm{ml}$ test solution contained $75 \mathrm{~g}$ anhydrous glucose and $1.6 \mathrm{~g}$ citric acid. After 12 hours fasting, a blood sample was obtained 120 minutes after ingestion of the solution. Samples after fasting and after two-hour ingestion were drawn into fluoridated tubes and centrifuged within 30 minutes. Plasma glucose was determined by hexokinase method and by enzymatic GOD-PAP method. Total cholesterol, HDL cholesterol, LDL cholesterol, and triglycerides were determined by an enzymatic method. All samples were analysed in the same E. Gulbis Central Laboratory.

Glucose tolerance was classified according to the WHO 1999 criteria (Anonymous, 1999b). Individuals who reported that they had diabetes were not included in the OGTT. Individuals who reported that they had type 1 diabetes $(n=2)$ were not included in the type 2 diabetes prevalence calculations as persons with disease.

Individuals who were on type 2 diabetes medication or had fasting plasma glucose level $\geq 7.0 \mathrm{mmol} / \mathrm{l}$ or $2 \mathrm{~h}$ plasma glucose $\geq 11.1 \mathrm{mmol} / 1$ were classified as type 2 diabetes (T2D). Those with $2 \mathrm{~h}$ plasma glucose $\geq 7.8$ and $<11.1$ $\mathrm{mmol} / \mathrm{l}$, and fasting plasma glucose $<7.0 \mathrm{mmol} / \mathrm{l}$ were classified as having IGT. IFG was defined as fasting plasma glucose $\geq 6.1$ but $<7.0 \mathrm{mmol} / \mathrm{l}$, and $2 \mathrm{~h}$ plasma glucose $<7.8 \mathrm{mmol} / \mathrm{l}$. Participants with T2D, IGT or IFG were classified as having abnormal glucose tolerance.

The study protocol was approved by the Central Medical Ethics Committee of Latvia. All the participants gave their written informed consent prior participation to the study.

Statistical analyses were performed with SPSS for Mac version 16.1. Significant differences in continuous variables were calculated using independent samples t-tests and chisquare tests for categorical variables. Analyses were stratified by gender and adjusted for age. The performance of the FINDRISC questionnaire with respect to AGT was assessed by calculating receiver operating characteristics (ROC) 
curves, sensitivity and specificity. The areas under the curve (AUC) with the respective 95\% confidence intervals (CI) were used for determination of the optimal cut-off level.

The level of statistical significance was set to 0.05 .

\section{RESULTS}

The baseline characteristics of the study population are presented in Table 1 . The prevalence of overweight and obesity was $72 \%$ in men and $71 \%$ in women. Only $38 \%$ of men and $20 \%$ of women had a normal waist circumference. Whereas a majority of men $(79 \%)$ and women $(80 \%)$ consumed fruits or vegetables daily, the prevalence of daily 30 minutes physical activity was very low with approximately only one out of 16 men and one out of 12 women complying with the recent recommendations. Smoking prevalence was higher in men $(30 \%)$ than in women $(17 \%)$. In respect to plasma lipids, women had higher mean levels of total cholesterol, HDL and LDL cholesterol levels than men whereas men had higher mean triglyceride levels compared to women (1.77 mmol/l versus $1.48 \mathrm{mmol} / \mathrm{l})$.

Women with AGT had a statistically significantly higher prevalence of overweight and obesity as well as central obesity $(P$ values $<0.001)$ compared to women with normal

Table 1

SAMPLE SIZE CHARACTERISTICS OF STUDY PARTICIPANTS ACCORDING TO GENDER

\begin{tabular}{|c|c|c|}
\hline Parameters & Men & Women \\
\hline $\mathrm{n}$ & 85 & 171 \\
\hline \multicolumn{3}{|l|}{ Age } \\
\hline $45-54$ years & $26 \%$ & $32 \%$ \\
\hline $55-64$ years & $31 \%$ & $31 \%$ \\
\hline$>65$ years & $43 \%$ & $37 \%$ \\
\hline \multicolumn{3}{|l|}{ Body mass index (BMI) } \\
\hline$<25 \mathrm{~kg} / \mathrm{m}^{2}$ & $28 \%$ & $29 \%$ \\
\hline $25-30 \mathrm{~kg} / \mathrm{m}^{2}$ & $49 \%$ & $42 \%$ \\
\hline$>30 \mathrm{~kg} / \mathrm{m}^{2}$ & $23 \%$ & $29 \%$ \\
\hline \multicolumn{3}{|l|}{ Waist circumference } \\
\hline$<80 \mathrm{~cm}$ (women) $;<94 \mathrm{~cm}$ (men) & $38 \%$ & $20 \%$ \\
\hline 80-88 cm (women); 94-102 cm (men) & $27 \%$ & $27 \%$ \\
\hline$>88 \mathrm{~cm}$ (women); > $102 \mathrm{~cm}$ (men) & $35 \%$ & $53 \%$ \\
\hline Daily fruit consumption & $79 \%$ & $80 \%$ \\
\hline 30 min physical activity daily & $6 \%$ & $8 \%$ \\
\hline Hypertensive drug treatment & $42 \%$ & $60 \%$ \\
\hline Systolic blood pressure (mmHg) & $137(20)^{1}$ & $134(18)$ \\
\hline Diastolic blood pressure (mmHg) & $85(11)$ & $85(11)$ \\
\hline Total cholesterol (mmol/l) & $5.6(1.2)$ & $6.1(1.4)$ \\
\hline HDL cholesterol (mml/1) & $1.28(0.35)$ & $1.62(0.43)$ \\
\hline LDL cholesterol (mmol/l) & $3.51(1.04)$ & $3.72(1.12)$ \\
\hline Triglycerides (mmol/l) & $1.77(1.02)$ & $1.48(0.73)$ \\
\hline Plasma glucose, $0 \mathrm{~h}, \mathrm{mmol} / \mathrm{l}$ & $6.50(5.61)$ & $5.41(1.05)$ \\
\hline Plasma glucose, $2 \mathrm{~h}, \mathrm{mmol} / \mathrm{l}$ & $6.11(1.88)$ & $6.13(2.13)$ \\
\hline Smoking (\%) & $30 \%$ & $17 \%$ \\
\hline
\end{tabular}

$\overline{1 \text { mean (standard deviation) }}$ glucose tolerance (Table 2). Even though there was a tendency to have higher prevalence of obesity and central obesity in men, the difference was not statistically significant $(P$-value for obesity 0.11 and 0.347 for central obesity, respectively). There was no difference in the prevalence of daily fruit/ vegetable intake or daily 30 minutes physical activity between persons without and those with AGT, neither in men nor in women. Women with AGT had higher levels of systolic blood pressure $(P<0.001)$, diastolic blood pressure $(P<0.01)$ and serum triglycerides $(P=0.02)$. No statistically significant difference was found in risk factors of $\mathrm{T} 2 \mathrm{D}$ and cardiovascular diseases in men.

Table 3 presents the prevalence of AGT and T2D by gender according to different categories of FINDRISC points. The prevalence of AGT in men with 11-14 FINDRISC points was $33 \%$ and for those with $15-19$ points $-77 \%$. The corresponding prevalences in women were $8 \%$ (11-14 points) and $39 \%$ (15-19 points). In both genders all persons with 20 points or more had AGT.

Figures 1 and 2 show the ROC information for men and women. The area under curve for AGT was 0.76 (95\% CI $0.63-0.88)$ in men and 0.82 (95\% CI 0.74-0.90) in women. Using the risk score cut-off value of 11 to identify undiagnosed AGT resulted in a sensitivity of $80 \%$ in men and $90 \%$ in women. The corresponding false-positive rates were $52 \%$ in men and $56 \%$ in women.

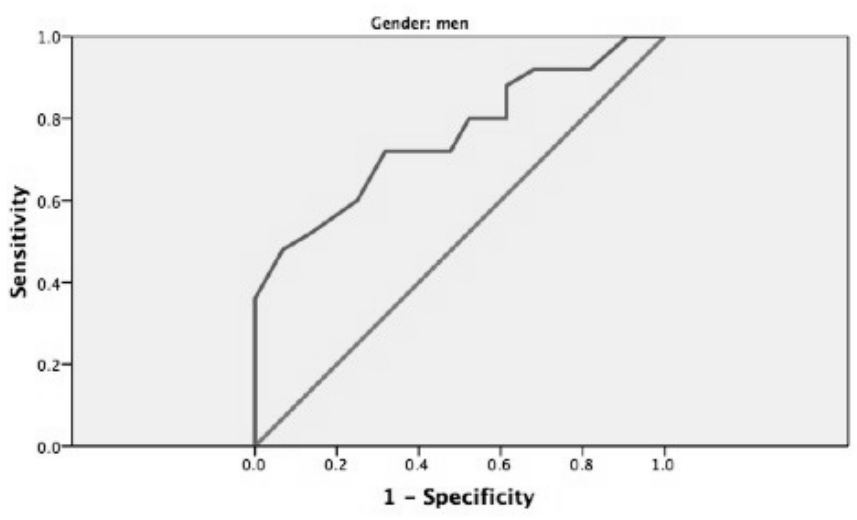

Fig. 1. Receiver operating characteristics (ROC) curves for the prevalence of abnormal glucose tolerance by FINDRISC in men.

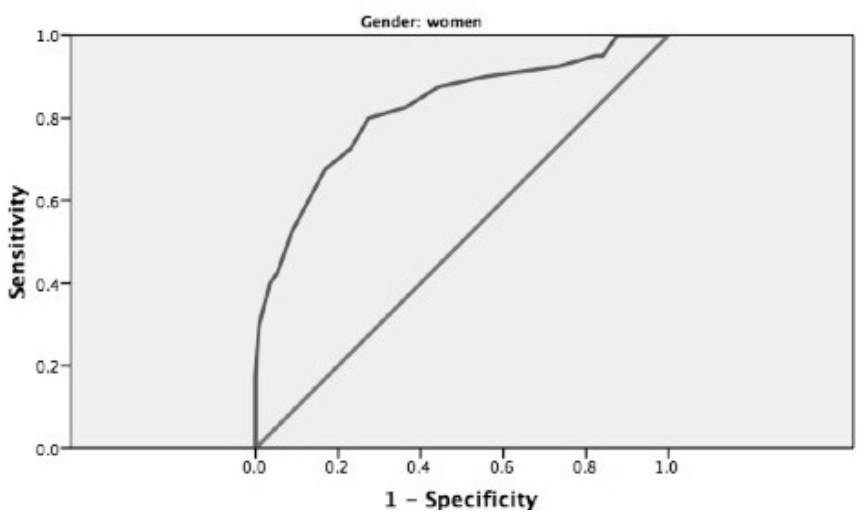

Fig. 2. Receiver operating characteristics (ROC) curves for the prevalence of abnormal glucose tolerance by FINDRISC in women. 
Table 2

DIFFERENCES IN RISK FACTORS OF GLUCOSE METABOLISM DISORDERS AND CARDIOVASCULAR DISEASES ACCORDING TO NORMAL (NGT) AND ABNORMAL GLUCOSE TOLERANCE (AGT) IN THE MIDDLE-AGED LATVIAN POPULATION BY GENDER

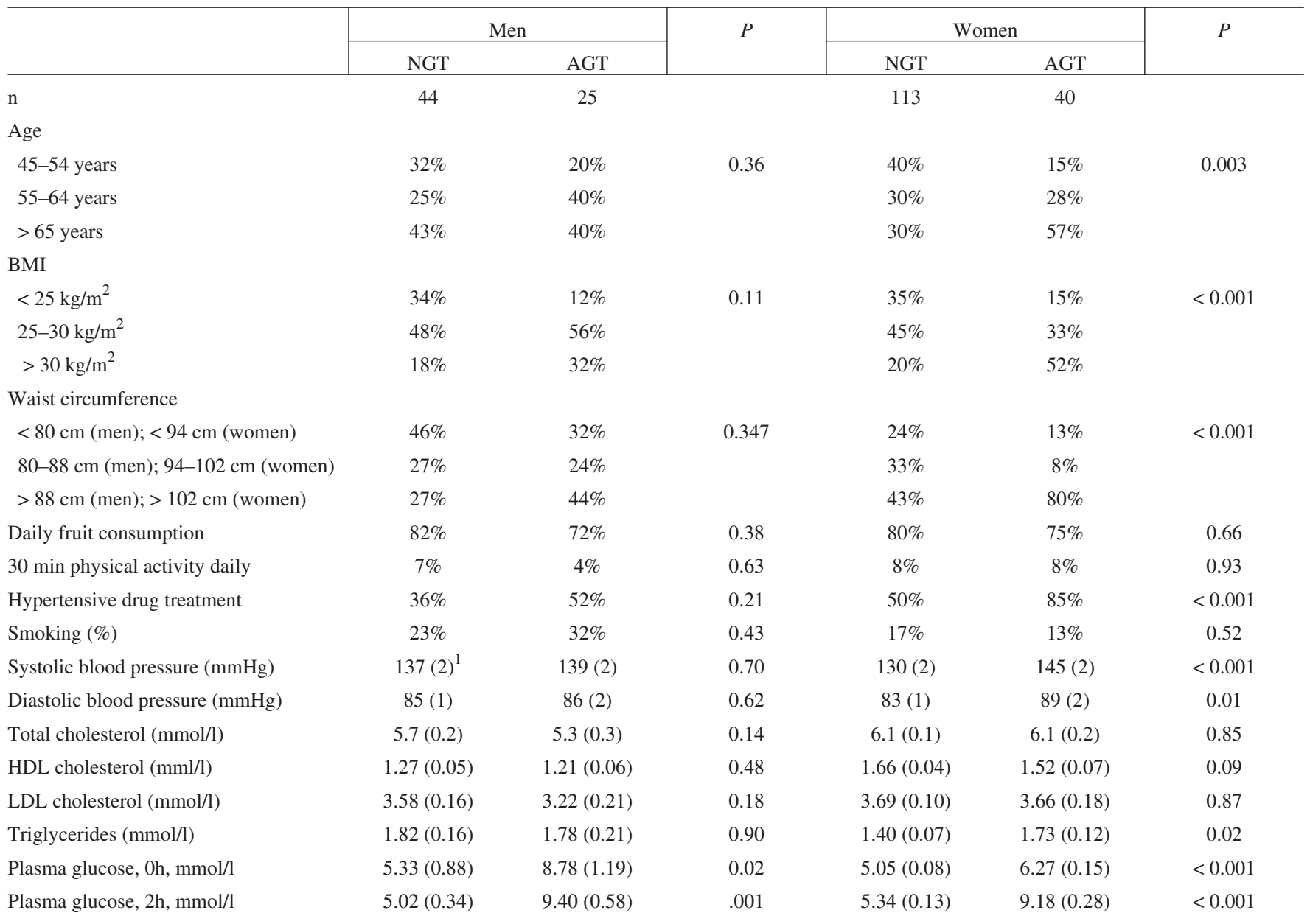

${ }^{1}$ age adjusted mean (standard error)

Table 3

PREVALENCE OF TYPE 2 DIABETES MELLITUS (T2D) AND ABNORMAL GLUCOSE TOLERANCE (AGT) IN 45-74 YEARS-OLD MEN AND WOMEN IN RIGA, LATVIA ACCORDING TO FINDRISC POINTS BY GENDER

\begin{tabular}{lcc|c}
\hline \multicolumn{2}{c|}{ FINDRISC points } & $\begin{array}{c}\text { T2D } \\
\%(\mathrm{n})\end{array}$ & $\begin{array}{c}\text { AGT } \\
\%(\mathrm{n})\end{array}$ \\
\hline Men & & & \\
& $0-3$ & $0 \%(0)$ & $0 \%(0)$ \\
& $4-6$ & $7 \%(1)$ & $13 \%(2)$ \\
& $7-10$ & $20 \%(3)$ & $36 \%(5)$ \\
& $11-14$ & $11 \%(3)$ & $25 \%(6)$ \\
& $15-19$ & $46 \%(6)$ & $75 \%(9)$ \\
$20-26$ & $100 \%(3)$ & $100 \%(3)$ \\
Women & & $0 \%(0)$ \\
& & & $10 \%(2)$ \\
& $4-6$ & $0 \%(0)$ & $7 \%(3)$ \\
$7-10$ & $5 \%(1)$ & $21 \%(8)$ \\
$11-14$ & $0 \%(0)$ & $53 \%(20)$ \\
$15-19$ & $8 \%(3)$ & $100 \%(7)$
\end{tabular}

\section{DISCUSSION}

Of all subjects who were categorised as AGT, more than a half were identified with elevated $2 \mathrm{~h}$ plasma glucose values while having normal fasting glucose values.

The overall prevalence of screen-detected abnormal glucose tolerance of $36.0 \%$ in men and $26 \%$ in women, respectively, are high. It is known that T2D usually starts slowly without typical symptoms of diabetes. Thus, it is obvious that many cases of T2D remain undiagnosed for years. Moreover, if only fasting glucose measurements are used to screen for $\mathrm{T} 2 \mathrm{D}$, a significant proportion of asymptomatic cases of diabetes remain undetected, as also demonstrated by the DECODE study (Anonymous, 1999a). Thus, the findings of our study provide further evidence that the measurement of fasting glucose alone cannot be considered as the sole indicator of abnormal glucose regulation in non-diabetics (Anonymous, 2003; Saaristo et al., 2008).

AGT such as impaired glucose tolerance (IGT) and impaired fasting glucose (IFG) are modifiable risk factors of T2D and cardiovascular diseases (Harris et al., 1996; Na- 
than et al., 2007). There is sufficient evidence from previous studies to conclude that the risk of developing AGT including T2D is closely linked to the presence and duration of overweight and obesity (Colditz et al., 1995; Must et al., 1999; Hu et al., 2001). Indeed, $88 \%$ of men and $85 \%$ of women with AGT in our study were either overweight or obese. This is in line with results from the Cooperative Health Research in the Region of Augsburg (KORA) survey conducted in 2000, showing that both BMI and waist circumference were significantly higher in men and women with abnormal glucose tolerance (Rathman et al., 2000). Moreover, Zargar et al. (2000) reported a 2.3-fold increase in risk of abnormal glucose tolerance in an Asian Indian population aged 40 years or over with $\mathrm{BMI}>25 \mathrm{~kg} / \mathrm{m}^{2}$.

Furthermore, many studies have showed that lifestyle intervention in people with impaired glucose tolerance (IGT) can result in sustained lifestyle changes and a reduction in diabetes incidence (Pan et al., 1997; Tuomilehto et al., 2001; Anonymous, 2002; Kosaka et al., 2005; Lindström et al., 2006; Ramachandran et al., 2006).

As the efficiency of risk scores may vary between populations with different ethnic backgrounds the risk scores should be validated in each population before use (Griffin $e t$ al., 2000; Hunt et al., 2002). Our results show that the FINDRISC questionnaire can be used as a self-administered tool to identify those with undetected AGT in the general Latvian population. The area under the ROC curve was $76 \%$ in men, respectively, $82 \%$ in women which is comparable to other risk scores developed to detect undiagnosed AGT or T2D (Baan et al., 1999; Park et al., 2002; Lorenzo et al., 2003; Glumer et al., 2004). The FINDRISC questionnaire identified $80 \%$ of men and $90 \%$ of women with previously undiagnosed AGT in Latvia using a cut-off level of 11 points. This is higher sensitivity compared to the Finnish study, validating the FINDRISC in the Finnish population in regard to detection of AGT (Saaristo et al., 2005).

Several clinical trials have convincingly showed that T2D can be prevented and/or delayed by lifestyle interventions. Thus, there is a need of a cost-effective tool in identifying people at risk in order to enroll them in activities that change unhealthy life-style habits, thus, decreasing the risk factors of T2D. The ideal tool would be to provide an OGTT to the entire middle-aged population. However, this is not feasible at the population level (Pan et al., 1997; Swinburn et al., 2001). Therefore, the FINDRISC questionnaire may help in identifying these people who may benefit from interventions or those worth for further testing for AGT using the OGTT (Griffin et al., 2000). The results from the Atherosclerosis Risk in Communities Study suggested that screening strategies based on fasting plasma glucose, complemented by clinical detection rules and /or an OGTT, are effective and practical in the detection of hyperglycemic states meriting clinical intervention (Schmidt et al., 2003).

The strength of this study is that it is based on a population sample of middle-aged men and women of all districts in Riga using oral glucose tolerance tests to detect AGT. However, several limitations of this study need to be considered.
Despite efforts to increase the response rate, only $22 \%$ of persons invited agreed to participate. The main reason of non-participations was the missing or incorrect information on the address of the potential participant. Non-participants might have had already abnormal glucose tolerance, and thus, they considered it unnecessary to take part in the survey. Therefore, the prevalence of AGT might have been underestimated.

In conclusion, our study showed that the prevalence of obesity, central obesity and physical inactivity were high in the Latvian population. Women with AGT had a worse risk factor profile for T2D and cardiovascular diseases compared to those with normal glucose tolerance. No differences were found in risk factor profile between men with and those without AGT. Furthermore, a high proportion of men and women with more than 11 FINDRISC points had undetected AGT. In addition, the results of our study revealed that the FINDRISC questionnaire can be used in clinical practice to detect AGT in the Latvian population.

\section{ACKNOWLEDGMENTS}

The work was supported by the National Research Programme in Medicine 2006-2009, project No. 14, „, Creation of the unified and generally accessible data base on the main life expectancy and life quality threatening pathologies and epidemiology of their risk factors in Latvian population”, and the Finnish Academy Grant. Our personal acknowledgment for their input to the whole team of the study including study coordinators Dita Ozola and Inga Prāne, colleagues from the E. Gulbis laboratory as well as to the colleagues who participated in the initial stage of the project particularly, Girts Brigís, Ieva Strēle and Madara Grīnšteine.

\section{REFERENCES}

Anonīms (2008). Sociālā sistēma un veselības aprūpe Rīgā 2007. gadā: Rīgas Domes Labklājības departamenta gadagrāmata [Social system and health care in Rìga in 2007]. Rìga, 7. lpp.

Anonymous (1999a). Is fasting glucose sufficient to define diabetes? Epidemiological data from 20 European studies. The DECODE Study Group. Diabetologia, 42, 647-654.

Anonymous (1999b). WHO Consultation: Definition, diagnosis and classification of diabetes mellitus and its complications. Part 1: diagnosis and classification of diabetes mellitus.

http://whqlibdoc.who.int/hq/1999/WHO_NCD_NCS_99.2.pdf

Anonymous (2000). World Health Organization Report No. 99.2. Report of WHO Consultation: Obesity: Preventing and managing the global epidemic. Geneva, WHO Technical Report Series, 894.

Anonymous (2002). Reduction in the incidence of type 2 diabetes with lifestyle intervention or metformin. Diabetes Prevention Program Research Group. New Engl. J. Med., 346, 393-403.

Anonymous (2003). Age- and sex-specific prevalences of diabetes and impaired glucose regulation in 13 European cohorts. The DECODE Study Group. Diabetes Care, 26, 61-69.

Anonymous (2005). IDF consensus worldwide definition of the metabolic syndrome. International Diabetes Federation.

http://www.idf.org/webdata/docs/MetSyndrome_FINAL.pdf

Baan, C.A., Ruige, J.B. \& Stolk, R.P. (1999). Performance of a predictive model to identify undiagnosed diabetes in a health care setting. Diabetes Care, 22, 213-19. 
Colditz, G.A., Willett, W.C., Rotnitzky, A., Manson J.E. (1995). Weight gain as a risk factor for clinical diabetes mellitus in women. Ann. Intern. Med., 122, 481-486.

Glumer, C., Carstensen, B., Sandbaek, A., Lauritzen, T., Jorgensen, T., Borch-Johnsen, K.A. (2004). Danish diabetes risk score for targeted screening: The Inter99 study. Diabetes Care, 27, 727-733.

Griffin, S.J., Little, P.S., Hales, C.N., Kinmonth, A.L., Wareham, N.J. (2000). Diabetes risk score: Towards earlier detection of type 2 diabetes in general practice. Diabetes Metab. Res. Rev., 16, 164-171.

Harris, M.I. (1996). Impaired glucose tolerance: Prevalence and conversion to NIDDM. Diabet Med., 13(Suppl), 9-11.

Hunt, K., Williams, K., Haffner, S., Stern, M. (2002). Predicting impaired glucose tolerance among individuals with non-diabetic fasting glucose value: The San Antonio Heart Study. Diabetes, 2, SA229.

Hu, F.B., Manson, J.E., Stampfer, M.J., Colditz, G., Liu, S., Solomon, C.G., Willet W.C. (2001). Diet, lifestyle, and the risk of type 2 diabetes mellitus in women. New Engl. J. Med., 345, 790-797.

King, H., Aubert, R.E., Herman W.H. (1998). Global burden of diabetes, 1995-2025: Prevalence, numerical estimates, and projections. Diabetes Care, 21, 1414-1431.

Knowler, W.C., Barrett-Connor, E., Fowler, S.E. (2002). Reduction in the incidence of type 2 diabetes with lifestyle intervention or metformin. New Engl. J. Med., 346, 393-403.

Kosaka, K., Noda, M., Kuzuya, T. (2005). Prevention of type 2 diabetes by lifestyle intervention: A Japanese trial in IGT males. Diabetes Res. Clin. Pract., 67, 152-162.

Lindström,.J., Tuomilehto, J. (2003). The diabetes risk score: A practical tool to predict type 2 diabetes risk. Diabetes Care, 26, 725-731.

Lindstrom, J., Ilanne-Parikka, P., Peltonen, M., Aunola, S., Eriksson, J.G., Hemiö, K., Hämäläinen, Härkönen, P., Keinänen-Kiukaanniemi, S., Laakso, M., Louheranta, A., Mannelin, M., Paturi, M., Sundvall, J., Valle, TT., Uusitupa, M., Tuomilehto, J. (2006). Sustained reduction in the incidence of type 2 diabetes by lifestyle intervention: Follow-up of the Finnish Diabetes Prevention Study. Lancet, 368, 1673-1679.

Lorenzo, C., Okoloise, M., Williams, K., Stern, M.P., Haffner, S.M. (2003). The metabolic syndrome as predictor of type 2 diabetes: The San Antonio heart study. Diabetes Care, 26, 3153-3159.

Kumanyika, S., Jeffery R.W., Morabia, A., Ritenbaugh C., Antipatis V.J. (2002). Obesity prevention: The case for action. Public Health Approaches to the Prevention of Obesity (PHAPO) Working Group of the International Obesity Task Force (IOTF). Int. J. Obes. Relat. Metab. Disord., 26, 425-436.

Must, A., Spadano, J., Coakley, E.H., Field, A.E., Colditz, G., Dietz, W.H. (2007). The disease burden associated with overweight and obesity. JAMA, 282, 1523-1529.

Nathan, D.M., Davidson, M.B., DeFronzo, R.A., Heine, R.J., Henry, R.R., Pratley, R., Zinman, B. (2007). ADA Consensus Statement. Impaired fasting glucose and impaired glucose tolerance: Implications for care. Diabetes Care, 30, 753-759.

Received 14 August 2009
Pan, X.R., Li, G.W., Hu, Y.H. (1997). Effects of diet and exercise in preventing NIDDM in people with impaired glucose tolerance. The Da Qing IGT and Diabetes Study. Diabetes Care, 20, 537-544.

Park, P.J., Griffin, S.J., Sargeant, L., Wareham, N.J. (2002). The performance of a risk score in predicting undiagnosed hyperglycemia. Diabetes Care, 25, 984-988.

Pīrāgs, V., Bricina, N., Dzērve, V. \& Eisaka, I. (2005). Pirmās nacionālās cukura diabēta skrīninga programmas DIA-screen rezultāti [The results of the first diabetes screening programme DIA-screen]. In: Latvijas Universitātes Raksti, Vol. 694, Medicīna, IV, 85.-91. lpp.

Pudule, I. (2007). Latvijas iedzīvotāju veselību ietekmējošo paradumu pétījums, 2006. [Health Behaviour among Latvian Adult Population, 2006]. Rīga: V/a Sabiedrības veselības aǵentūra. 165 lpp.

Ramachandran, A., Snehalatha, C., Mary, S., Mukesh, B., Bhaskar, A.D., Vijay, V. Indian Diabetes Prevention Programme (IDPP). (2006). The Indian Diabetes Prevention Programme shows that lifestyle modification and metformin prevent type 2 diabetes in Asian Indian subjects with impaired glucose tolerance (IDPP-1). Diabetologia, 49, 289-297.

Rathmann, W., Haastert, B., Icks, A., Löwel, H., Meisinger, C., Holle, R., Giani, G. (2000). High prevalence of undiagnosed diabetes mellitus in Southern Germany: Target populations for efficient screening. The KORA survey 2000. Diabetologia, 46, 182-189.

Saaristo, T., Peltonen, M., Linström, J., Saarikoski, L., Sundvall, J., Eriksson, J. G., Tuomilehto, J. (2005). Cross-sectional evaluation of the Finnish Diabetes Risk Score: A tool to identify undetected type diabetes, abnormal glucose tolerance and metabolic syndrome. Diabetes Vasc. Dis. Res., 2, 67-72.

Saaristo, T., Barengo, N. C., Korpi-Hyövälti, E., Oksa, H., Puolijoki, H., Saltevo, J. T., Vanhala, M., Sundvall, J., Saarikoski, L., Peltonen, M., Tuomilehto, J. (2008). High prevalence of obesity, central obesity and abnormal glucose tolerance in the middle-aged Finnish population. BMC Public Health, 8, 423-431.

Schmidt, M.I., Duncan, B.B., Vigo, A., Pankow, J., Ballantyne, C.M., Couper, D., Brancati, F., Folsom, A.R. for the ARIC investigators (2003). Detection of undiagnosed diabetes and other hyperglycemia states: The Atherosclerosis Risk in Communities Study. Diabetes Care, 26, 1338-1343.

Swinburn, B.A., Metcalf, P.A., Ley, S.J. (2001). Long-term (5-year) effects of a reduced-fat diet intervention in individuals with glucose intolerance. Diabetes Care, 24, 619-624.

Tuomilehto, J., Lindström, J., Eriksson, J.G. (2001). Prevention of type 2 diabetes mellitus by changes in lifestyle among subjects with impaired glucose tolerance. New Engl. J. Med., 344, 1343-1350.

Wild, S.G., Roglic, A., Green, R., Sicree, H., King, F. (2004). Global prevalence of diabetes: Estimates for the year 2000 and projections for 2030. Diabetes Care, 27, 1047-1053.

Zargar, A.H., Khan, A.K., Masoodi, S.R., Laway, B.A., Wani, A.I., Bashir, M.I., Dar, F.A. (2000). Prevalence of type 2 diabetes mellitus and impaired glucose tolerance in the Kashmir Valley of the Indian subcontinent. Diabetes Res. Clin. Pract., 47, 135-146.

\section{GLIKOZES METABOLISMA TRAUCĒJUMI UN 2. TIPA CUKURA DIABĒTA RISKA FAKTORI RĪGAS (LATVIJA) IEDZĪVOTĀJU VIDŪ VECUMĀ NO 45 LİDZ 74 GADIEM}

Pētījuma mērḳis bija noteikt pašreizējo glikozes metabolisma traucējumu prevalenci Latvijas iedzīvotāju vidū vecumā no 45 līdz 74 gadiem, kā arī salīdzināt riska profilu cilvēku grupām ar un bez glikozes metabolisma traucējumiem. Sekundārais pētījuma mērḳis bija zinātniski apstiprināt Somu Diabēta riska rādītāja (Finnish Diabetes Risc Score - FINDRISC) anketu kā metodi, kas identificē glikozes metabolisma traucējumus Latvijas iedzīvotājiem vidēja vecuma grupā. Laikposmā no 2008. gada aprīḷa līdz 2009. gada martam tika veikts šķērsgriezuma pētījums, kā paraugkopu izvēloties cilvēku grupu vecumā no 45 līdz 74 gadiem un tos nejaušināti atlasot no Rīgas ğimenes ārstu reğistriem. Pētījumā tika izmantota aptaujas anketa, veikti objektīvi mērījumi - auguma, svara, vidukḷa apkārtmērs, asinsspiediens; pētījuma sastāvdalıa bija arī laboratoriskā sadaḷa - glikozes tolerances tests, holesterīna un tā frakciju noteikšana asins paraugos. Pētījuma rezultāti parādīja, ka Latvijas populācijā ir augsta centrālās aptaukošanās prevalence, kā arī samazināts fiziskās aktivitātes līmenis. Sievietēm ar glikozes metabolisma traucējumiem ir augstāks 2. tipa cukura diabēta un kadiovaskulāro saslimšanu risks, salīdzinot ar sievietēm, kurām ir normāls glikozes metabolisms. Salīdzinot vīriešu grupu ar un bez glikozes metabolisma traucējumiem, netika atrastas statistiski ticamas atškiirības riska faktoru profilā. Daudz biežāk glikozes metabolisma traucējumi tika konstatēti tiem vīriešiem un sievietēm, kuriem FINDRISC anketā bija vairāk nekā 11 punkti. FINDRISC anketu var izmantot Latvijas iedzīvotājiem, lai klīniskā praksē identificētu cilvēkus ar glikozes metabolisma traucējumiem. 